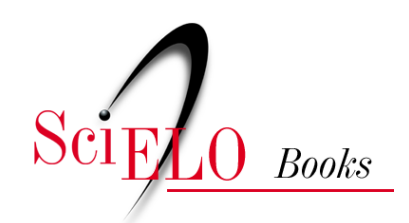

\title{
Madeireira Lumber
}

\author{
José Carlos Radin \\ Gentil Corazza
}

\section{SciELO Books / SciELO Livros / SciELO Libros}

RADIN, J.C., and CORAZZA, G. Madeireira Lumber. In: Dicionário histórico-social do Oeste catarinense [online]. Chapecó: Editora UFFS, 2018, pp. 93-96. ISBN: 978-85-64905-65-8. https://doi.org/10.7476/9788564905658.0021.

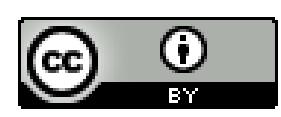

All the contents of this work, except where otherwise noted, is licensed under a Creative Commons Attribution 4.0 International license.

Todo o conteúdo deste trabalho, exceto quando houver ressalva, é publicado sob a licença Creative Commons Atribição $\underline{4.0}$.

Todo el contenido de esta obra, excepto donde se indique lo contrario, está bajo licencia de la licencia $\underline{\text { Creative Commons }}$ Reconocimento 4.0. 


\section{Madeireira Lumber}

A Madeireira Lumber, como ficou conhecida, foi a maior e mais impactante da região Oeste catarinense, nas primeiras décadas do século XX. O nome completo da empresa era Southern Brazil Lumber \& Colonization Company. Ela fazia parte do Grupo Farquhard, um conjunto de empresas de origem norte-americana, que atuava em nível mundial em vários ramos de atividades, mas principalmente em ferrovias, portos e navegação. Como seu próprio nome diz, ela era mais propriamente uma empresa de colonização, mas no Oeste catarinense deixou sua marca, sobretudo nas atividades relacionadas à madeira.

A exploração da madeira como atividade econômica nas matas da região começa a ganhar importância, a partir da decadência do ciclo da erva-mate, nas primeiras décadas do século XX. De início, a madeira era explorada de forma artesanal pelos caboclos e colonos, que a beneficiavam através de engenhos de serrar, hidráulicos ou de tração animal, com fins de utilização doméstica. Além do próprio consumo, uma parte da madeira bruta explorada principalmente pelas madeireiras do Oeste, situadas em Chapecó e região, era comercializada, a partir do porto de Goio-En, através do rio Uruguai, durante os períodos de cheia. As toras de madeira eram embarcadas em forma de jangadas e levadas para a Argentina, seu grande mercado consumidor externo. A construção da ferrovia, em 1910, trouxe grande impulso às atividades de beneficiamento e comercialização das madeireiras oriundas do Vale do rio do Peixe e proximidades da ferrovia. Durante a Guerra do Contestado, 1912 a 1916, e Primeira Guerra Mundial, a atividade madeireira voltou a cair, para consolidar-se como atividade econômica dominante, na década de 1920 em diante. No auge do ciclo também era um dos principais itens de exportação catarinense, sobretudo para os mercados do centro do país. Aproximadamente $80 \%$ da produção local de madeira era destinada aos mercados de São Paulo e Rio de Janeiro. O restante da produção seguia para Argentina e Uruguai. $\mathrm{O}$ avanço do processo de colonização também contribui enormemente para a derrubada das matas e para a expansão das atividades 
madeireiras. Ao redor dessas indústrias da madeira, muitos núcleos e vilas foram se formando.

A Lumber estava autorizada a instalar-se na região, desde 1909, mas só começou a operar efetivamente, em 1911, depois de concluídas as obras da estrada de ferro que ligava São Paulo ao Rio Grande do Sul. Para facilitar os trabalhos da madeireira, seu proprietário, Percival Farquhar, mandou construir um ramal ferroviário ligando a madeireira à estação de trem de Porto União, no intuito de facilitar a exploração da madeira ao longo da ferrovia.

A empresa assumiu proporções gigantescas e transformou-se em uma das maiores serrarias da América Latina. Ela chegou a possuir nada menos do que 276 mil alqueires de terra, o equivalente a 669 mil hectares ou aproximadamente 28 mil lotes agrícolas, cobertos de matas, onde havia mais de quatro milhões de pinheiros e mais dois milhões de árvores nobres, como imbuias e cedros, chegando muitos deles a atingir 30 metros de altura e mais de um metro de diâmetro. Sua principal serraria era a Madeireira de Três Barras, a maior da América Latina na época, que tinha a capacidade de serrar $300 \mathrm{~m}^{3}$ de madeira por dia, o equivalente a 1.200 dúzias de tábuas e contava com mais de 800 empregados. Junto à Madeireira de Três Barras ela construiu um núcleo urbano de 250 casas para abrigar seus funcionários mais graduados. A Lumber tinha também uma serraria em Calmon, mais ao norte, próximo a Porto União, na divisa com o Paraná. Para facilitar o trabalho de derrubada das árvores, ela avançou trilhos mata adentro, os quais muitas vezes ultrapassavam os 30 quilômetros. Seus guindastes com longos cabos de aço alcançavam um diâmetro de até 200 metros. Suas modernas máquinas de serrar realizavam o trabalho de mais de cinco mil trabalhadores usando equipamentos convencionais.

Desde o fim da Guerra do Contestado e durante toda a década de 1920, a empresa foi hegemônica na extração e comercialização de madeira. Na década seguinte, foram criadas inúmeras serrarias de pequeno porte, que vieram a dar um novo impulso à atividade de extração de madeira, sem, contudo, ameaçar o domínio da Lumber. Em 1936, três estações de trem se destacavam em volume transportado: Caçador, Canoinhas e Três Barras. Em 1940, o montante exportado 
de madeira beneficiada na região do Contestado chegou a representar 19,10\% da totalidade das exportações catarinenses.

A Lumber de Três Barras construiu um mundo à parte no interior das matas da região. Uma cidade particular, com mais de 200 casas para os executivos e uma centena de outras para abrigar seus mais de 800 operários. Governada com suas próprias leis, funcionava como um verdadeiro território norte-americano dentro do país. As casas para os empregados superiores dispunham de água encanada, energia elétrica e aquecimento central. Havia também quadras de tênis para uso exclusivo dos diretores e de seus filhos. Até uma sala de projeção de filmes foi criada para a diversão dos operários. Todo esse complexo era muito bem protegido por pistoleiros armados, trazidos dos Estados Unidos.

O ciclo da madeira alcança seu auge entre 1930 e 1950 e termina uma década mais tarde, com o esgotamento dos pinhais de corte e de outras madeiras nobres. As atividades madeireiras contribuíram também para o povoamento e a urbanização da região, através das vilas rurais, onde residiam os trabalhadores das serrarias. Muitas dessas vilas se transformaram, depois, em municípios. No entanto, o ciclo da madeira pouco contribuiu para a formação inicial do capital na região, mas deixou como herança a devastação quase completa das matas, que antes cobriam esse imenso território. Só sobraram em torno de $2 \%$ delas.

Com o desenvolvimento da indústria madeireira, as próprias relações de trabalho foram se alterando, com a progressiva introdução do trabalho assalariado em substituição ao trabalho dos peões e dos diaristas. As condições de trabalho costumavam ser muito precárias, sem amparo legal e sem assistência médica e previdenciária, e os salários eram muito baixos. Por outro lado, sem uma política de controle, a exploração desenfreada da madeira provocou o rápido extermínio das florestas nativas e o fim do ciclo madeireiro. Além do extermínio das florestas, a atividade madeireira pouco contribuiu para a acumulação de capital na região, apesar de ter sido muito importante para os colonos que ali se instalavam, por fornecer a madeira para suas casas e demais instalações. Na verdade, o capital gerado pela indústria 
madeireira evadiu-se e deixou como herança, nessa região, um dos mais baixos índices de desenvolvimento humano. Em 1938, Getúlio Vargas estatizou a Lumber, que havia pedido concordata.

\section{REFERÊNCIAS}

BAVARESCO, Paulo Ricardo. Os Ciclos Econômicos do Extremo Oeste Catarinense: modernização, progresso e empobrecimento.(Dissertação de Mestrado). Blumenau, 2003.

POLI, Jaci. Caboclo: pioneirismo e marginalização. Cadernos do CEOM, Chapecó: Argos, 1995.

VALENTINI, Delmir José. A Guerra do Contestado (1912-1916). In: RADIN, José Carlos; VALENTINI, Delmir José; ZARTH, Paulo A.

História da Fronteira Sul. Porto Alegre: Letra\&Vida, 2015.

. Memórias da Lumber e da Guerra do Contestado. Porto Alegre:

Letra \& Vida; Chapecó: UFFS, 2015. 